\title{
Karst Aquifer Recharge: Comments on Somaratne, N. Characteristics of Point Recharge in Karst Aquifers. Water 2014, 6, 2782-2807
}

\section{Adrian D. Werner 1,2}

1 School of the Environment, Flinders University, GPO Box 2100, Adelaide SA 5001, Australia; E-Mail: adrian.werner@flinders.edu.au; Tel.: +61-8-8201-2710; Fax: +61-8-8201-2676

2 National Centre for Groundwater Research \& Training, Flinders University, GPO Box 2100, Adelaide SA 5001, Australia

External Editor: Miklas Scholz

Received: 17 October 2014; in revised form: 11 November 2014 / Accepted: 24 November 2014 / Published: 28 November 2014

\begin{abstract}
The article "Characteristics of Point Recharge in Karst Aquifers, Water 6: 2782-2807" by N. Somaratne evaluates various recharge estimation techniques applied to four limestone aquifers in South Australia. Somaratne [1] concludes that methods based on watertable fluctuations, groundwater modelling and water budgets are independent of recharge processes, and are therefore superior to the chloride mass balance (CMB) approach for karst aquifers. The current comment offers alternative interpretations from existing field measurements and previous literature, in particular for the Uley South aquifer, which is the focus of much of the article by Somaratne [1]. Conclusions regarding this system are revised, partly to account for the misrepresentation of previous studies. The aeolianite sediments of Uley South are mostly unconsolidated or poorly consolidated, and dissolution features in the calcrete capping provide point infiltration into a predominantly unconsolidated vadose zone, whereas Somaratne's [1] findings require that the system comprises well-developed conduits in otherwise low-conductivity limestone. Somaratne's [1] assertion that the basic premise of CMB is violated in Uley South is disputable, given strong evidence of relatively well-mixed groundwater arising from mostly diffuse recharge. The characterization of karst aquifer recharge should continue to rely on multiple techniques, including environmental tracers such as chloride.
\end{abstract}

Keywords: karst aquifers; point recharge; chloride mass balance; Australia 


\section{Introduction}

The article "Characteristics of Point Recharge in Karst Aquifers, Water 6: 2782-2807" by Somaratne [1] examines recharge to four limestone aquifers in South Australia, and discusses the applicability of various recharge estimation approaches to these types of settings. The research aims to explore the contributions to total recharge from point sources, relative to diffuse recharge, using water isotopes, major ions, watertable responses to rainfall, and chloride mass balance (CMB) calculations. Based on a critique of recharge estimation methods and their applicability to karst systems, Somaratne [1] concludes that methods based on watertable fluctuations, numerical groundwater modelling and water budgets are independent of recharge processes, and are, therefore, superior to the CMB approach. The current comment aims to demonstrate that alternative conclusions to those of Somaratne [1] can be drawn from available field measurements and previous literature. Much of the article by Somaratne [1] focuses on the Uley South aquifer, and as a co-author of several of the cited investigations of Uley South hydrogeology, the conclusions regarding this system are found to require revision. The comments that follow are subdivided into two sections: (1) Uley South recharge processes; and (2) Uley South Recharge: Methods and Estimates.

\section{Uley South Recharge Processes}

Some of the key hydrogeological features of Uley South basin are characterized differently in previous literature, relative to the account given by Somaratne [1], and there are important implications for the ensuing discussion of recharge estimation methods. The following provides a brief review of critical hydrogeological aspects of Uley South, aimed at enhancing the investigation of recharge by Somaratne [1].

Somaratne [1] draws parallels in the recharge processes occurring within the Uley South and Gambier Limestone aquifers, as well as other limestone systems. The Gambier Limestone was deposited on a cool-water open marine shelf and reflects restricted terrestrial influence [2]. The region is known for its cenotes and extensive cave systems [3]. In Uley South, groundwater is extracted from Quaternary limestone (QL), so-called the Bridgewater Formation, which has considerably different characteristics to the Gambier Limestone. The Uley South QL comprises aeolian sediments including fine sand-sized shell fragments, which are generally either unconsolidated or loosely aggregated $[4,5]$. Some mobile sand dunes remain. Significant caves have not been discovered [6], although in places, the QL is more consolidated, and a region of very high hydraulic conductivity values $(>1000 \mathrm{~m} / \mathrm{d})$ in the central western portion of the basin suggests that consolidated sediments containing high-flow dissolution features occur locally [5,7]. Differences in the morphologies of the Bridgewater Formation and the Gambier Limestone have important implications for recharge estimation, thereby adding to the findings of Somaratne [1], as discussed in more detail below.

Surface calcrete is evident over extensive areas of Uley South. Secondary cementation has also led to multiple calcrete horizons within the unconsolidated QL sediments, potentially restricting vertical flows [6], including in areas of deep unsaturated zones. The sinkholes in Uley South, referred to throughout the article [1], are predominantly solution features within the calcrete capping. Martin and Clarke [8] describe the QL calcrete as a thin veneer, 10-20 cm thick, and peppered with dissolution 
cavities, and Morton and Steel [9] found it to be extensively fractured. Evans [4] refers to a well-dispersed network of solution features with diameters down to $0.01 \mathrm{~m}$. The calcrete is more extensive in places with dissolution features of diameters and depths up to $2.5 \mathrm{~m}$. Nonetheless, the limited depth of sinkholes over the majority of Uley South is such that there are no known dissolution features that reach the watertable within the basin. A simple schematic of the upper subsurface across most of Uley South is given in Figure 1.

Figure 1. Schematic of the upper subsurface conditions typical of Uley South (not to scale).

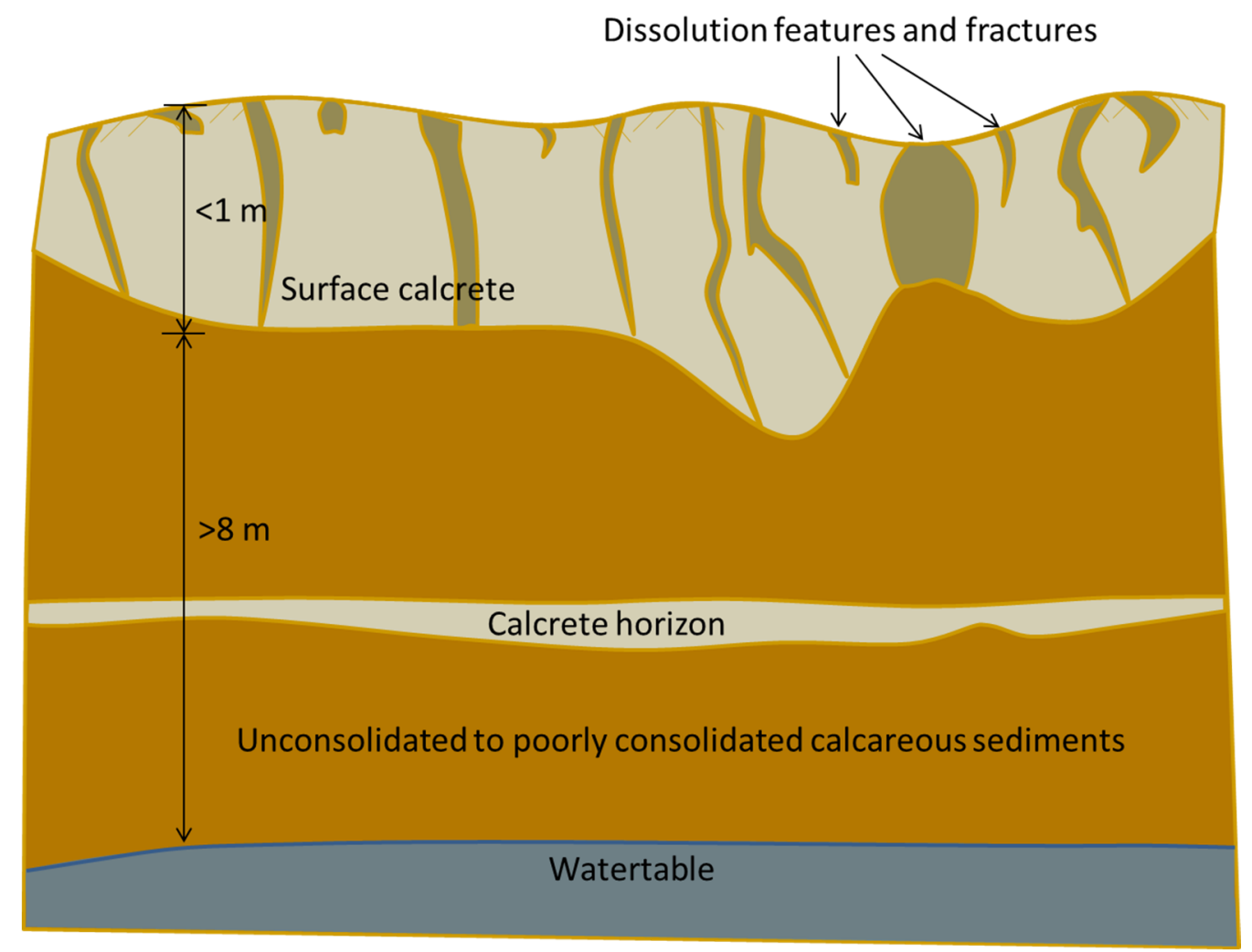

A number of the statements by Somaratne [1] differ to the upper subsurface characteristics of Uley South described by previous authors [4,5,8,9], and as illustrated in Figure 1. For example, the "duality of flow regime" (pp. 2782-2783, 2802) occurs only through the surface calcrete within most areas of Uley South. There is no evidence that infiltration persists as discrete components of point and diffuse recharge to the watertable, because the unsaturated zone contains primarily unconsolidated materials. This does not preclude strong seasonal recharge. However, mixing of diffuse and point infiltration within the unsaturated zone is unavoidable across the majority of the basin. Calcrete horizons within the unconsolidated sediments are expected to further diffuse influxes of point infiltration through calcrete dissolution features. While the system is characterized by extensive point infiltration, Somaratne's [1] notion of "point recharge" in Uley South (pp. 2782-2785, 2799-2802), whereby dissolution features lead to recharge with the chemical qualities of surface runoff, remains unsubstantiated. In a recent modelling study of Uley South recharge [10], the timing and magnitude of simulated recharge relative to field measurements of watertable fluctuations and chloride indicated that bypass flow (i.e., point infiltration) most likely persisted only to a depth of a few meters into the unsaturated zone of Uley South. 
Mixing within the saturated zone is expected to add to the mixing processes of the unsaturated zone in Uley South. The extremely transient nature of rainfall to the area will no doubt lead to seasonal influxes of freshwater and significant variations in groundwater velocities. In the case of the highly transmissive and heavily pumped Uley South aquifer, small groundwater mounds that might occur under any major recharge point sources, during the wet season, would surely spread and disperse with the ambient groundwater during the extended dry season, during which time pumping rates are highest. It is expected that this will lead to strong mixing between different water types within the aquifer, due to the enhanced dispersive processes that accompany strongly transient systems. Hence, the seemingly stable freshwater pockets in the vicinity of point recharge referred to by Somaratne [1] (pp. 2799 and 2802) are unlikely to persist in the long-term, as supported by the lack of field evidence for these, and given the results of a previous investigation showing strong mixing down-gradient of point recharge areas in South Australian karst aquifers [11].

The description of Uley South by Somaratne [1] can be modified to better accord with previous literature. Firstly, the "Tertiary clay unit of 5-25 m thickness" (p. 2786) is in fact discontinuous and there are significant areas where the QL is in direct contact with the underlying Tertiary sand, or is underlain by basement rock [4,5]. This has implications for the mixing of groundwater from different depths and between the Quaternary and Tertiary aquifers of Uley South. Secondly, the groundwater flow direction is not "from north-east to south-west" (p. 2786), but rather there is evidence of westerly groundwater flow toward Coffin Bay in the north-western part of the basin [4]. This is important for any water balance analysis of the aquifer aimed at inferring recharge. Further, the suggestion that "vegetation is sparse in both basins, except on sand dunes" (p. 2794) is not consistent with the observations of others, and rather, significant forests are found in areas of Uley South that are greater than $30 \mathrm{~m}$ above sea level, and the western sand dunes are almost void of vegetation [12]. Additionally, the "topographical rises of dry limestone" (p. 2786) are not allogenic, but are autogenic because they fall within the basin's recharge zone, despite their higher topography and QL base elevation. These aspects are also critical to the characterization of Uley South recharge.

Somaratne's [1] finding of "one sinkhole per $0.07 \mathrm{~km}^{2}$ with approximate size ranging from 0.4 to $2.5 \mathrm{~m}$ diameter" (p. 2786) offers a rather arbitrary definition that a sinkhole is at least $0.4 \mathrm{~m}$ in diameter. An assessment of Uley South recharge should consider the high density of dissolution features with diameters down to $0.01 \mathrm{~m}$, as identified by Evans [4] and others, because these will generate more diffusive infiltration than Somaratne's [1] depiction of relatively sparse, large sinkholes at some $260 \mathrm{~m}$ intervals (i.e., $0.07 \mathrm{~km}^{2}$ per sinkhole) in Uley South. Additionally, the Coffin Bay aquifer is described by Somaratne [1] as the "diffuse recharge aquifer of adjacent Coffin Bay fresh water lens" (p. 2793). However, the Coffin Bay system also has surface calcrete overlying unconsolidated sediments containing hard bands of calcrete [13,14], and the point versus diffuse recharge distinction between Uley South and Coffin Bay aquifers is unsubstantiated. Added to this, Somaratne's [1] categorization of the two basins into diffuse and point recharge settings is in opposition to his suggestion that the "Uley South basin water level rise is negligible" at "the lower end of annual rainfall", whereas "such a lower end could not be confirmed for Coffin Bay lens A". It would seem that the opposite would apply if the characteristics of recharge in the two basins (i.e., diffuse recharge in Coffin Bay lenses and point recharge in Uley South) suggested by Somaratne [1] were correct. 
Somaratne [1] cites Martin et al.'s [15] (wrongly referred to as "Martin and Screaton, 2006") study of the Floridan aquifer system, which is a dual-porosity system involving flow in and between karst conduits and the porous matrix. Somaratne [1] concludes that "even if an extensive monitoring network is established, the tendency is to monitor long-term resident chloride concentration of matrix porosity as evident in Uley South basin" (p. 2802). A number of modifications to these concepts can be drawn from previous literature, including: (1) Martin et al. [15] clearly highlight that the matrix and karst conduits readily exchange water (and, therefore, solutes) and hence the occurrence of relatively old and more saline groundwater in the matrix does not follow logically from this reference, even for systems with major conduit networks; (2) Uley South groundwater flow is not dominated by karst conduit flows, and the extensive unconsolidated deposits are less likely to contain particularly old, saline groundwater relative to settings comprising fissured and/or karstified low-permeability rocks; and (3) Evans [4] measured stable isotopes of oxygen and hydrogen, carbon isotopes $\left({ }^{13} \mathrm{C}\right.$ and $\left.{ }^{14} \mathrm{C}\right)$, and chlorofluorocarbons (CFC-11 and $\mathrm{CFC}-12)$ in an attempt to characterize groundwater and recharge processes in Uley South, and concluded that diffuse recharge is the dominant process, and that groundwater residence times are less than 20 years, in contradiction to the notions posed by Somaratne [1]. It is also noteworthy that sampling methods involving pumping from observation wells or samples taken from water supply wells will extract from higher permeability sediments preferentially where these intercept the well intake. Further, groundwater samples are usually a mixture of waters from different depths. Given the number of extraction and observation points in Uley South, it is unlikely that high flow pathways are entirely avoided. In combination, these factors seem to contradict Somaratne's [1] suggestion that Uley South field samples do not account for the low-chloride groundwater that might derive from sinkhole infiltration and recharge.

There are important implications of the high density of dissolution features in the Uley South calcrete, and the more diffusive recharge mechanisms that occur within the unconsolidated vadose zone. For example, it is largely impossible to discern whether a groundwater sample is taken "at or near point recharge sources" (p. 2792) in Uley South, because of the countless dissolution pathways through the calcrete. In addition to unsaturated zone processes, the groundwater flow through saturated, unconsolidated sediments would tend to further enhance the mixing between ambient groundwater and any "point recharge sources", should the latter exist, as discussed above. Herczeg et al. [11] provide supporting evidence for this. They found that point-source recharge to South Australian karst aquifers was detectable only on a local scale, i.e., point-source recharge and regional groundwater were indistinguishable after flow distances of $150 \mathrm{~m}$. Water chemistry and isotopic interpretations indicated that point sources contribute less than $10 \%$ of total recharge, with diffuse recharge providing the remainder. Herczeg et al. [11] also found that sinkhole recharge was subjected to a small degree of evaporation.

The consideration of vegetation controls on Uley South recharge, and the influence of vegetation on the application of recharge estimation methods require further consideration. For example, a study of evapotranspiration rates in Uley South by Swaffer et al. [16] used plot-scale measurements to show that recharge in Uley South during two below-average recharge years was negligible under the two main tree species of the catchment, whereas bare ground recharge was some $63 \mathrm{~mm} / \mathrm{year}$. Notwithstanding that recharge calculations were subject to significant measurement uncertainty, these findings demonstrate the critical importance of accounting for vegetation controls on recharge, even in 
regions with strong point infiltration. Additionally, these results highlight that vegetation are able to extract significant amounts of water from the unsaturated zone in Uley South [11], arguably in contradiction to Somaratne's [1] sinkhole concepts of point recharge that essentially bypasses the vadose zone. A recent investigation into vegetation influences on chloride loads to Uley South [17] demonstrated high variability in chloride loads to the land surface due to the chloride-capture effects of Uley South vegetation. The implications for CMB estimates of groundwater recharge were found to be significant, although further evaluation of vegetation stand "edge effects" are needed to narrow uncertainty bounds on revisions to CMB-based Uley South recharge [17]. These factors add to the challenges of quantifying the total chloride load to the land surface (i.e., computing both wet and dry deposition) in applying the CMB approach [18]. Considering these studies, and the analysis of vegetation effects on Uley South recharge by Ordens et al. [10], it is clear that a more thorough evaluation of evapotranspiration controls than that considered by Somaratne [1] is necessary in any assessment of recharge mechanisms in Uley South.

\section{Uley South Recharge: Methods and Estimates}

Somaratne [1] offers several statements about methods of karst aquifer recharge estimation, some of which are applied to the four study areas, which require additional discussion. The watertable fluctuation (WTF) method is discussed first in what follows. Where Somaratne [1] considers the "average basin water level rise during recharge periods" (p. 2795), the reduction in pumping that occurs during wet seasons should also be considered, because this contributes to water-level rise, at least in the vicinity of pumping wells. A method for modifying the WTF method of recharge estimation to achieve this is given by Ordens et al. [12]. In karst systems with significant secondary porosity, the specific yield $\left(S_{y}\right)$ that underpins the WTF approach may not be a single, unique value. Shevenell [19] demonstrates that karst systems with well-developed conduits may have three alternative $S_{y}$ values, one each for the fractured, matrix and conduit systems, and these can vary by an order of magnitude. As such, any localized recharge may produce a series of groundwater waves through the aquifer, travelling at different rates through the various pathways, thereby producing complex watertable response-recharge relationships. Evans [4] suggests that WTF behavior is indeed complicated in Uley South because of porosity variability, albeit it is not clear whether this refers to saturated or unsaturated zone processes.

The lack of intermediate points in the $\delta^{18} \mathrm{O}$-chloride relationship for Uley South groundwater samples is discussed at length by Somaratne [1]. However, the article reports incorrectly on statements by Ordens et al. [12] regarding the cause of this. On page 2799, Somaratne [1] states that "these authors argued that the contribution to recharge by flow through sinkholes is only a small fraction of total recharge based on a lack of intermediate data points" (i.e., in the $\delta^{18} \mathrm{O}$-chloride relationship). No such conclusion was made by Ordens et al. [12], who, rather, conclude that the lack of intermediate data is attributable to complete evaporation and/or transpiration of recharge water before it reaches the watertable or the screens of monitoring wells. They state that "the contribution of sinkhole-channelled rainfall that escapes evapotranspiration contributes only little to the total recharge amount". In other words, while sinkholes act as preferential infiltration pathways, there is a lack of evidence of direct sinkhole recharge to the watertable that remains unmixed with ambient groundwater [12]. The 
misdiagnosis of the $\delta^{18} \mathrm{O}$-chloride relationship for Uley South, regarding the lack of intermediate data points, is devised only by Somaratne [1]. The suggestion by Somaratne [1] that the lack of intermediate data points "may result from monitoring bias" (p. 2799) seems unlikely given the abundance of measuring sites and the high density of dissolution features in the Uley South calcrete [12]. Added to this, if a major proportion of the Uley South recharge is through sinkholes reaching the watertable (thereby avoiding evaporation), large groundwater bodies with surface water characteristics are more likely to occur in the unconsolidated Uley South sediments. Hence, this too is counter to the idea of monitoring bias, and appears as self-contradiction within the article. Further, Evans [4] reports that the relatively uniform isotopic composition $\left(\delta^{18} \mathrm{O}\right.$ and $\left.\delta^{2} \mathrm{H}\right)$ along the direction of flow in the Uley basin indicates a single recharge process, rather than significant localized recharge as might occur under the mechanisms suggested by Somaratne [1].

One of the main conclusions of Somaratne [1] is the contention that the CMB approach is invalid in karst settings, including for the Uley South system. The basis for this is that point recharge is poorly represented by groundwater chloride measurements. Aside from the misrepresentation of previous Uley South literature by Somaratne [1], as discussed above, a number of other corrections to the CMB concepts presented within the article are warranted. For example, Somaratne [1] does not distinguish necessarily between unsaturated and saturated forms of the CMB approach, and yet there are several important differentiating assumptions and limitations of the two methods that are highlighted by Wood [20]. The unsaturated zone CMB method is more sensitive to temporal variability in chloride fluxes to the land surface and other atmospheric-soil zone factors (e.g., [21], incorrectly defined in Somaratne's [1] references list), compared to the saturated zone CMB, and, hence, the need for a "steady influx of water and chloride" (p. 2784) can be somewhat relaxed for saturated zone applications. Evans [4] follows this notion in applying the CMB approach to the saturated zone to estimate Uley South recharge, despite observing "saw-toothed shaped hydrographs" (p. 2796) in response to rainfall. Somaratne [1] attributed this hydrograph behavior to sinkhole recharge, whereas the same trends would arise from widespread infiltration through a dense array of sinkholes into an otherwise unconsolidated vadose zone, in particular where this contains sandy sediments and in places overlies a somewhat shallow watertable. Somaratne's [1] assertion that the total basin recharge, discerned from applying the saturated-zone CMB approach, and the diffuse recharge "are similar in magnitude" (p. 2801), lacks evidence. Alcalá et al. [22] draw opposing conclusions in their application of the CMB approach to a carbonate aquifer with appreciable concentrated recharge. Further, there seems little basis for the suggestion that "there is nothing to be gained by further improving data for application of the conventional CMB" (p. 2802) given the need to improve knowledge of land surface chloride loads $[17,18]$.

Somaratne [1] misrepresents the findings of several previous studies, in support of the proposition that the CMB method under-estimates recharge in Uley South. For example, in Table 2 (p. 2801), the range for "total recharge from the Conventional $\mathrm{CMB}$ " from Ordens et al. [12] is reported as $53-60 \mathrm{~mm} /$ year. The reported range is $52-63 \mathrm{~mm} /$ year [12], and Ordens et al. [12] add that the effect of aerosol salt-accumulation by vegetation may increase these figures by some $28 \%$, amongst other unknowns. In Table 2 of Somaratne [1], the recharge obtained from the WTF method by Ordens et al. [12] is also misrepresented as $129 \mathrm{~mm} /$ year, which should rather be the range 47-129 mm/year [12]. Somaratne [1] also suggests that the CMB estimates of recharge are "significantly lower than recharge 
estimated using WTF method and by groundwater modelling" (p. 2801). To support this claim, a value of $146 \mathrm{~mm} /$ year is offered in Table 2 from a groundwater flow modelling report by Werner [23]. However, the report considers a range of recharge scenarios which adopt values of 109-169 mm/year based on 1D soil models, and makes the following recommendation "it is suggested that future modelling of Uley South consider a larger set of recharge realisations". Furthermore, no attempt was made to calculate recharge using the groundwater flow model of Uley South [23], in contradiction to the assertion by Somaratne [1]. Finally, Somaratne [1] cites the recharge modelling study of Ward et al. [24] and includes a value of $75 \mathrm{~mm} /$ year as their estimate of runoff in Uley South based on the curve number approach. However, Ward et al. [24] clearly state that the modelled predictions of recharge were "relative rates only" rather than "absolute predictions for water resources management", and were unverified and not compared to other estimates. For that reason, they did not provide absolute values of recharge and runoff for individual basins, and therefore it appears that the estimate provided by Somaratne [1] was not obtained from Ward et al. [24].

Somaratne's [1] suggestion that "watertable fluctuation, numerical groundwater modelling, Darcy flow calculation or water budget methods" (p. 2802) are more suitable for recharge estimation in point-recharge dominant basins because they are "independent of the particular mode of recharge" is highly debatable. The WTF approach is dependent on $S_{y}$, which may comprise multiple components representing different water storage mechanisms in aquifers that are fissured, porous and karstifed [25]. Amongst the systems considered by Somaratne [1], these conditions are likely to occur in the Gambier Limestone, and with a reduced effect in the Bridgewater formation of Uley South aquifer due to the predominance of unconsolidated sediments. Numerical groundwater modelling commonly assumes an equivalent porous medium approach to groundwater flow in karstified/fissured systems, and as such, will fail to capture accurately the groundwater responses to recharge at certain scales. Additionally, there is inherent non-uniqueness in the parameters of groundwater models, and this poses significant challenges in their application to recharge estimation. The same issue applies to Darcy flow calculations. Water budget methods also contain considerable uncertainties because of difficulties in determining evapotranspiration rates in karst systems [16], but, also, these are influenced by the same equivalent porous medium approximations as Darcy flow calculations. Scanlon et al. [26] highlight that estimates based on surface water methods provide potential recharge (i.e., an over-estimate), whereas groundwater-based approaches are more likely to produce actual recharge rates. It is clear that none of these methods is "independent of the particular model of recharge" (p. 2802), as reported by Somaratne [1]. Rather, best practice is to apply a suite of methods, bearing in mind the limitations and quantifying the degree of uncertainty in each approach, to obtain a balanced view of recharge, including for karst systems [26,27]. Eliminating the CMB approach from the suite of tools available for recharge estimation can only reduce the potential knowledge of recharge processes that are attainable from readily available field measurements. Obviously, quantification of recharge from the CMB approach requires especially careful application and consideration of the processes associated with the movement of chloride and water inputs from the atmosphere to the watertable, including infiltration, runoff and runon, vegetation effects, and groundwater flow and mixing, regardless of the setting. 


\section{Conclusions}

The estimation of recharge to karst aquifers is an area requiring significant research effort. Karst aquifer recharge may involve both diffuse and preferential flow processes. This duality of flow mechanisms complicates the quantification of recharge, runoff and evapotranspiration in karst settings. The study by Somaratne [1] refers extensively to the Uley South aquifer in assessing recharge methods to South Australian karst limestone systems. It is reported that recharge to Uley South is under-estimated by some 2.8 times using the CMB approach, by comparing to alternative methods. Somaratne [1] suggests that this is caused by the duality of recharge, whereby the contribution of point sources to groundwater chloride concentrations is under-represented in Uley South sampling strategies.

A key issue in the study by Somaratne [1] is that aquifers comprising well-cemented limestones and unconsolidated or loosely cemented sediments are lumped together. However, karst conduits (caves) carry the bulk of groundwater flow in well-cemented limestones, similar to those that characterize much of North America, Europe and the Gambier Limestone of southeast South Australia. On the other hand, some limestone aquifers have a high proportion of unconsolidated sediments interbedded with calcrete horizons, such as Uley South and other aeolianite systems of South Australia, and the majority of groundwater flow occurs through granular porosity, with fewer well-developed karst conduits within the saturated zone $[7,28,29]$. There is no doubt that the surface calcrete of Uley South leads to high infiltration rates, evidenced by high proportions of rainfall becoming recharge (e.g., $>10 \%$ of rainfall) [12]. However, the subsurface characteristics of Uley South likely invoke significant mixing between water originating from point and diffuse infiltration, allowing for the application of the $\mathrm{CMB}$ method pending proper consideration of the particular features the system. The dissolution features in Uley South's surface calcrete may in fact enhance rates of evaporation from the unsaturated zone, above those considered in previous studies, and further work is warranted to determine whether sinkholes act as preferential evaporation pathways, in addition to their role in preferential infiltration.

Somaratne's [1] assertion that the basic premise of CMB is violated in Uley South is disputable, because it may be possible to obtain useful insights into recharge from CMB calculations if recharge areas and pathways are discernible within the aquifer, and can be attributed to the resulting spatial variability in groundwater chloride concentrations. Clearly, mixing between groundwaters in karst conduits and the rock matrix needs to be considered in applying CMB methods, but nonetheless, the evapo-concentration of chloride in groundwater samples remains a mass-conservative indicator of rainfall partitioning into evapotranspiration and recharge, and one that offers useful independence from methods that consider only water fluxes.

Considerable water level declines have been observed in Uley South over several decades of extraction, despite pumping at rates thought to be only $40 \%$ of long-term recharge. Hence, where studies offer significantly increased values of recharge in regions with widespread historical declines in groundwater levels, a precautionary principle is recommended. The study by Somaratne [1] lacks the usual caveats regarding both uncertainty and the plausibility of alternative, feasible conceptual models for recharge processes. The current comment shows that the conclusion by Somaratne [1] that recharge to Uley South has been grossly under-estimated by others is disputable.

This comment demonstrates that the interpretations and conclusions of Somaratne [1] regarding Uley South recharge values and methodologies are debatable, and are founded on several 
misrepresentations of previous studies. Alternative interpretations apply if a distinction is made between the morphologies of different limestone aquifers. Otherwise, the conclusions regarding the lack of applicability of the CMB approach to Uley South recharge estimation appear to be premature. In analyzing limestone aquifers with strong groundwater flow through conduits, the spatial averaging adopted by Somaratne [1] seems generally unsuitable, given the variability inherent in heavily karstified systems.

It should be noted that much of the feedback presented in the current comment was offered through the review process of a Discussion Paper on this topic involving the same author [30]. The reader is directed to the interactive discussion comments on that manuscript for a multi-authored rebuttal of the current research [31].

\section{Acknowledgments}

The helpful comments of three anonymous reviewers are gratefully acknowledged.

\section{Conflicts of Interest}

The author declares no conflict of interest.

\section{References}

1. Somaratne, N. Characteristics of point recharge in karst aquifers. Water 2014, 6, 2782-2807.

2. Webb, J.A.; Grimes, K.G.; Lewis, I.D. Volcanogenic origin of cenotes near Mt Gambier, southeastern Australia. Geomorphology 2010, 119, 23-35.

3. Grimes, K.G. The southeast karst province of South Australia. Environ. Geol. 1994, 23, 134-148.

4. Evans, S.L. Estimating Long Term Recharge to Thin, Unconfined Carbonate Aquifers Using Conventional and Environmental Isotope Techniques: Eyre Peninsula, South Australia. Master Thesis, Flinders University, Adelaide, Australia, 1997.

5. Harrington, N.; Evans, S.; Zulfic, D. Uley Basin Groundwater Modelling Project, Vol. 1: Project Overview and Conceptual Model Development; Report DWLBC 2006/01; Department of Water, Land and Biodiversity Conservation: Adelaide, Australia, 2006.

6. Twidale, C.R.; Bourne, J.A. Dolines of the Pleistocene dune calcarenite terrain of western Eyre Peninsula, South Australia: A reflection of underprinting? Geomorphology 2000, 33, 89-105.

7. Sibenaler, X.P. Eyre Peninsula Groundwater Survey Uley South Basin, Progress Report No. 4: Aquifer Evaluation; Report book 76/30; South Australian Department of Mines: Adelaide, Australia, 1976.

8. Martin, R.; Clarke, D. South Eyre Peninsula Basins: Uley Basin Review; Report Book 2000/00008; Primary Industries and Resources, South Australia: Adelaide, Australia, 2000.

9. Morton, W.M.; Steel, T.M. Evaluation of aquifers in the Uley South groundwater basin, southern Eyre Peninsula. Miner. Resour. Rev. 1970, 128, 33-48.

10. Ordens, C.M.; Post, V.E.A.; Werner, A.D.; Hutson, J.L. Influence of model conceptualisation on one-dimensional recharge quantification: Uley South, South Australia. Hydrogeol. J. 2014, 22, 795-805. 
11. Herczeg, A.L.; Leaney, F.W.J.; Stadter, M.F.; Allan, G.L.; Fifeld, L.K. Chemical and isotope indicators of point source recharge to karst aquifers, South Australia. J. Hydrol. 1997, 192, 271-299.

12. Ordens, C.M.; Werner, A.D.; Post, V.E.A.; Hutson, J.L.; Simmons, C.T.; Irvine, B.M. Groundwater recharge to a sedimentary aquifer in the topographically closed Uley South Basin, South Australia. Hydrogeol. J. 2012, 20, 61-72.

13. Parker, A.J.; Fanning, C.M.; Flint, R.B. Geology. In Natural History of Eyre Peninsula; Twidale, C.R., Tyler, M.J., Davies, M., Eds.; Royal Society of South Australia Inc.: Adelaide, Australia, 1985; pp. 21-55.

14. Schwarz, M.P. Lincoln map sheet. In Geological Atlas 1:250,000 Series; Sheet SI 53-11; South Australian Geological Survey, Department of Primary Industries and Resources: Adelaide, Australia, 2002.

15. Martin, J.M.; Screaton, E.J.; Martin, J.B. Monitoring Well Response to Karst Conduit Head Fluctuations: Implications for Fluid Exchange and Matrix Transmissivity in the Floridan Aquifer; Geological Society of America Special paper 404; Department of Geological Sciences, University of Florida: Gainesville, FL, USA, 2006; pp. 209-217.

16. Swaffer, B.A.; Holland, K.L.; Doody, T.M.; Li, C.; Hutson, J.L. Water use strategies of two co-occurring tree species in a semi-arid karst environment. Hydrol. Process. 2014, 28, 2003-2017.

17. Bresciani, E.; Ordens, C.M.; Werner, A.D.; Batelaan, O.; Guan, H.; Post, V.E.A. Spatial variability of chloride deposition in a vegetated coastal area: Implications for groundwater recharge estimation. J. Hydrol. 2014, 519, 1177-1191.

18. Alcalá, F.J.; Custodio, E. Spatial average aquifer recharge through atmospheric chloride mass balance and its uncertainty in continental Spain. Hydrol. Process. 2014, 28, 218-236.

19. Shevenell, L. Analysis of well hydrographs in a karst aquifer: Estimates of specific yields and continuum transmissivities. J. Hydrol. 1996, 174, 331-355.

20. Wood, W.W. Use and misuse of the chloride-mass balance method in estimating ground water recharge. Ground Water 1999, 37, 2-3.

21. Gee, G.W.; Zhang, Z.F.; Tyler, S.W.; Albright, W.H.; Singleton, M.J. Chloride mass balance: Cautious in predicting increased recharge rates. Vadose Zone J. 2005, 4, 72-78.

22. Alcalá, F.J.; Cantón, Y.; Contreras, S.; Were, A.; Serrano-Ortiz, P.; Puigdefábregas, J.; Solé-Benet, A.; Custodio, E.; Domingo, F. Diffuse and concentrated recharge evaluation using physical and tracer techniques: Results from a semiarid carbonate massif aquifer in southeast Spain. Environ. Earth Sci. 2011, 62, 541-557.

23. Werner, A.D. A Groundwater Model of Uley South Basin, South Australia; Report produced for the Eyre Peninsula Natural Resources Management Board by Flinders University: Adelaide, Australia, 2010.

24. Ward, J.D.; Hutson, J.L.; Howe, B.; Fildes, S.; Werner, A.D.; Ewenz, C. A Modelling Framework for the Assessment of Recharge Processes and Climate Change; Report developed through the Eyre Peninsula Groundwater, Allocation and Planning Project; Eyre Peninsula Natural Resources Management Board, Government of South Australia: Port Lincoln, Australia, 2009.

25. Zuber, A.; Motyka, J. Hydraulic parameters and solute velocities in triple-porosity karstic-fissured-porous carbonate aquifers: Case studies in southern Poland. Environ. Geol. 1998, $34,243-250$. 
26. Scanlon, B.R.; Healy, R.W.; Cook, P.G. Choosing appropriate techniques for quantifying groundwater recharge. Hydrogeol. J. 2002, 10, 18-39.

27. Andreu, J.M.; Alcalá, F.J.; Vallejos, Á.; Pulido-Bosch, A. Recharge to aquifers in SE Spain: Different approaches and new challenges. J. Arid Environ. 2011, 75, 1262-1270.

28. Barnett, S.R. Eyre Peninsula Groundwater Survey Uley South Basin, Progress Report No. 5: Water Balance and Safe Yield; Report Book No. 78/22; Department of Mines and Energy: Adelaide, Australia, 1978.

29. Davis, A.; Munday, T.; Somaratne, N. Characterisation of a coastal aquifer system in the Eyre Peninsula, South Australia, using nuclear magnetic resonance methods. In Groundwater in the Coastal Zones of the Asia-Pacific, Coastal Research Library 7; Wetzelhuetter, C., Ed.; Springer: Dordrecht, The Netherlands, 2013; pp. 89-120.

30. Somaratne, N.; Smettem, K.; Lawson, J.; Nguyen, K.; Frizenschaf, J. Hydrological functions of sinkholes and characteristics of point recharge in groundwater basins. Hydrol. Earth Syst. Sci. Discuss. 2013, 10, 11423-11449.

31. Hydrology and Earth Systems Sciences Interactive Discussion: Hydrological functions of sinkholes and characteristics of point recharge in groundwater basins by Somaratne et al., 2013. Available online: http://www.hydrol-earth-syst-sci-discuss.net/10/11423/2013/hessd-10-114232013-discussion.html (accessed on 17 October 2014).

(C) 2014 by the authors; licensee MDPI, Basel, Switzerland. This article is an open access article distributed under the terms and conditions of the Creative Commons Attribution license (http://creativecommons.org/licenses/by/4.0/). 